\title{
Kompetence a školní praxe Rozpaky oborového didaktika nad kurikulární reformou
}

\author{
František Kuřina
}

Katedra matematiky, Přírodovědecká fakulta, Univerzita Hradec Králové

Tento článek je inspirován kritickými hodnoceními české kurikulární reformy publikovanými v roce 2013 v časopise Pedagogická orientace Stanislavem Štechem a Tomášem Janíkem. V roce 2003 jsem napsal: „Za 60 let svých kontaktů se školou jsem zažil řadu reforem. Snad pro všechny bylo charakteristické, že začaly cosi nově organizovat, aniž by se poučily v dobrém či špatném z výchozího stavu“ (Kuřina, 2003, s. 322). Je tomu patrně stejně i u současného reformního snažení, které je založeno na dokumentech Bílá kniha (2001) a Rámcové vzdělávací programy (2002). Cíle předpokládané reformy jsou pozoruhodné:

Dosáhnout vyšší kvality a funkčnosti vzdělávání tvorbou nových vzdělávacích a studijních programů, které budou odpovídat požadavkům informační a znalostní společnosti, udržitelného rozvoje, zaměstnanosti a potřebám aktivní účasti na životě demokratické společnosti v integrované Evropě a které budou zároveň respektovat individuální odlišnosti a životní podmínky účastníků vzdělávání. (Bílá kniha, 2001, s. 18)

V roce 2009 jsem připomněl, že „naše pedagogická věda dosud působení Bílé knihy nezhodnotila“ (Kuřina, 2009, s. 299). Sám jsem již v roce 2003 napsal:

Přesun tvorby osnov na jednotlivé školy znamená neobyčejně silné zatížení učitelů a v důsledku toho nebezpečí formální realizace základních cílů reformy. Obávám se, že v praxi může reforma znamenat i snížení úrovně naší vzdělávací soustavy. (Kuřina, 2003, s. 323)

V roce 2013 jsme se hodnocení reformy dočkali. V úvodu citované stati Štech konstatuje, že školská praxe a většina učitelů reformu, která způsobila na mnohých školách roztrpčení a zmatek, nepřijala (Štech, 2013, s. 617). Se znalostí světové literatury formuluje dále v českém prostředí nové kritické pohledy na kompetence, transfer a pedagogický výzkum. Cílem mého př́spěvku je vyslovit souhlas se zmíněnými autory a formulovat stanoviska 
k pojmům transfer a gramotnost. Dále se budu zabývat, ovlivněn i Janíkovým článkem, otázkami, které jsou podle mého názoru aktuální pro matematické vzdělávání v naší současné škole.

\section{Kompetence, řešení úloh a transfer}

Česká kurikulárníreforma byla v podstatě bezprostřední (copy-paste) aplikací doporučení, která přicházela od Světové banky, OECD, Evropské komise a dalších institucí (Štech, 2013, s. 617). Je výrazem rezignace na tradiční cíle všeobecného vzdělání a jejich nahrazení schopnostmi a kompetencemi:

Za orientací vzdělávání na kompetence se skrývají hlavně ekonomické cíle posloužit trhu práce. I přes chlácholivé řeči zastánců tohoto př́istupu vede $\mathrm{k}$ zanedbání práce s učivem, nevede $\mathrm{k}$ aktivizaci žáků $\mathrm{v}$ učení a místo stimulace pedagogické inovativnosti zavádí učitelskou praxi do byrokratické rutiny. (Štech, 2013, s. 622)

Pojem kompetence chápe Štech jako „schopnost jednat, jejímiž stavebními kameny jsou vědomosti a dovednosti, avšak tato schopnost se na ně nedá redukovat" (2013, s. 623). Ačkoliv nebylo jasné ani jak tento přesun cílů vzdělávání realizovat, ani co to bude z dlouhodobé perspektivy znamenat, byla reforma spuštěna. Přitom podle Štecha „konceptoři kurikulární reformy ignorovali i výsledky pedagogicko-psychologického výzkumu učení“ (2013, s. 625). Štech dále připomíná známou Brunerovu tezi, že „myšlení jako takové neexistuje, myšlení je vždycky myšlením o něčem“ (2013, s. 629). Na adresu př́iznivců kurikula kompetencí Štech uvádí následující analogii francouzského autora N. Baillargeona: „Hledají, jak rozvinout kreativitu jako takovou nebo obecnou schopnost řešit problémy a podobně. Je to tak trochu, jako bychom po škole žádali, aby naučila žáky hrát - bez ohledu na to, zda půjde o hokej, karty nebo šachy" (2013, s. 630). Kompetenci nelze nikdy oddělit od jejího konkrétního oborového obsahu:

Umět vyřešit kvadratickou rovnici, to je kompetence. Umět řešit problémy - to není žádná kompetence, to je prázdná floskule... nanejvýš může jít o spekulaci psychologů. Avšak současný stav empirických výzkumů nedovoluje takovou spekulativní konstrukci jakkoli potvrdit. (Štech, 2013, s. 629)

Tím se dostáváme k pedagogicky závažným otázkám, které spolu souvisejí: k otázce řešení úloh a otázce transferu. Se Štechovými názory na kompetence rád a vřele souhlasím. K tematice úloh a transferu se nyní vyjádřrím podrobněji. 
Souhlasím s tím, že pojem transferu „jako schopnosti přenášet známé poznatky a dovednosti do zcela nové situace" (Štech, 2013, s. 630) není opodstatněný. Tuto tezi vyslovil kdysi i můj univerzitní učitel Bohumil Bydžovský (1880-1969) a mohu ji doložit i třemi anekdoticky vyznívajícími př́klady. Významný francouzský matematik, profesor Sorbonny Michel Chasles (1793-1880), jehož výsledky se dodnes citují, prokázal „bezbřehou naivitu“, když mu jako milovníku historie a nadšenému sběrateli prodal „velmistr padělatelství" Denis Vrain Lucas (z jehož dílny vyšly např. dokumenty s podpisy Galilea, Shakespeara, Voltaira, Sokrata, Pythagora i Archimeda) korespondenci Blaise Pascala s Isaacem Newtonem. Přestože bylo Newtonovi teprve 12 let a v dokumentech byly výrazné rozpory, věril Charles padělateli bez jakýchkoliv důkazů, ačkoliv matematickou větu by bez důkazů nepřijal. Tento skutečný př́iběh popisuje nejen český spisovatel žijící ve Francii Patrik Ouředník (2013), ale např. i americký historik matematiky Dirk J. Struik (1963). V románu amerického spisovatele Henryho Millera (1891-1980) se přiznává jistý právník: „Ve všem kromě právních záležitostí jsem totální pitomec“ (Miller, 1995, s. 27). Před několika lety se mi stala tato př́íhoda: Večer zvoní u nás doma telefon. Podle svého zvyku se představím: „Tady Kuřina." Z druhého konce drátu se ozve: „Si to ty?“ Matematik, který mi volal, zcela vypnul své obvyklé uvažování i selský rozum, nebot' na svoji otázku mohl dostat jedinou odpověd': „Ano“, at' by byl u telefonu kdokoli.

Ovšem transfer může být chápán i „volněji“: jako „snaha reagovat podobně v podobné životní situaci“ (Good, 1959, s. 578). Jiří Mareš to vykládá konkrétněji:

Dítě, dospívající i dospělý přecházejí z jedné školní a životní situace do druhé. Do každé nové situace si s sebou přenášejí zkušenosti z oněch předchozích. [...] Přenášejí si (transferují) propracované znalosti, emocionální prožitky i sociální zkušenosti získané při dolad'ování se k požadavkům všech předchozích situací. (Mareš, 2001, s. 402)

V tomto smyslu je transfer účinným pomocníkem ve vzdělávání. Je to v souladu nejen s myšlenkami Hanse Selyeho, že „myšlenkové celky obsahují minulé zkušenosti, nedovedeme uvažovat o věcech, které mají vlastnosti, s nimiž jsme se nikdy nesetkali“ (1975, s. 348), ale i s názory Komenského: „Učiti se znamená kráčeti k znalosti věci neznámé přes nějakou známou. Celé vyučování i učení sestává z př́kladů, pouček a napodobení“ $(1946$, s. 23, 33). Takže podle mého názoru je v naznačeném smyslu transfer přece jen „kamenem mudrců“ školní pedagogiky. 
Využití transferu ve vyučování můžeme doložit př́klady z matematiky. Odkazuji zde na Hejného sérii úloh o plotu (Hejný \& Kuřina, 2009, s. 36), na vytváření představ o přirozených číslech na začátku školní docházky, na propedeutiku algebraických zákonitostí zákonitostmi aritmetickými apod. Na transferu je založena idea názornosti (vytváření modelů, kreslení, obrázků...). Matematickou analogií transferu jsou morfismy (viz např. Hejný \& Kuřrina, 2009, s. 212).

Nevím, kdo zdůvodnil řešení problémů jako nejefektivnější podoby vyučování (Štech, 2013, s. 626). Já s tím nesouhlasím. Problémové vyučování nelze pokládat za jedinou formu vzdělávání. Již proto ne, že předpokladem úspěchu při něm je dostatek času a dobrá úroveň učitele. Výsledky problémového vyučování nelze dost spolehlivě ani předvídat, ani časově plánovat. Zastávám však stanovisko, že úlohy jsou nezastupitelnou složkou školní matematiky a souhlasím se Štechovým názorem, že při řešení úloh je nevyhnutelná dobrá znalost „matematického řemesla“, které bohužel naše škola nerozvíjí vždy dostatečně. (Kư̌ina, 1976, s. 190)

\section{Co s reformou?}

Podnícen názory Tomáše Janíka, že

současná kurikulární reforma stěží pozvedne kvalitu výuky, nebot' její implementace vyústila v nezvladatelný formalismus, a že na řadě škol je tvorba školních vzdělávacích programů vnímána jako něco, co odvádí učitele od samotné výuky, tedy od toho, co je hlavním posláním a co zakládá důvod existence školy (Janík, 2013, s. 636, 654),

jsem přesvědčen, že tato reforma nemá perspektivu. Podle Stanislava Štecha „interpretace, která ř́ká, že jádro reformy je zdravé, logika reformy je správná, jen je špatně implementována, neobstojí" (2013, s. 618). A to navzdory názorům Jany Strakové, která

považuje za zásadní reformu nezpochybňovat a naopak zdůrazňovat její bezesporné aspekty, tedy potřebu přizpůsobit vzdělávací cíle a obsah vzdělávání změnám ve společnosti a zaměřit se přitom na klíčové kompetence specifikované v rámcových vzdělávacích programech. (2013, s. 740)

Straková považuje „zpochybňování reformy za nebezpečné, nebot' sděluje učitelům, že práce, kterou v minulých letech investovali do realizací reformy, byla zcela zbytečná" (2013, s. 740). Obávám se, že tuto skutečnost není třeba učitelům sdělovat, oni to dobře vědí. 
Připomeňme v této souvislosti názory několika učitelů z praxe.

- Kurikulární reformou se snižuje míra vzdělanosti.

- Z žáků se vychovávají primitivové bez konkrétních znalostí, ale s hypertrofovanou komunikační kompetencí.

- Dobrý učitel reformu nepotřebuje. Všechno je v osobním přístupu a nasazení, vztahu k žákům a v odpovědnosti k budoucnosti. (Janík et al., 2010, s. 122, 141).

Zpochybňování reformy podle Strakové „podrývá již tak malou důvěru pedagogů v moudrost tvůrců vzdělávacích politik a posiluje jejich demotivovanost“ (2013, s. 740). To je patrně pravda, ale na základě čeho mají učitelé věřit $\mathrm{v}$ onu deklarovanou moudrost?

Podle Jany Strakové

největší nedostatek implementace reformy spočívá $v$ přecenění profesní vyspělosti všech zapojených aktérů. „Nedostatečná“ vyspělost tvůrců dokumentu se projevila $\mathrm{v}$ tom, že $\mathrm{v}$ dokumentech poskytli učitelům málo vodítek, která by jim umožňovala nové vzdělávací cíle uchopit, prioritizovat a smysluplně zakomponovat do běžné výuky. Pravděpodobně proto, že i oni měli nejasnou představu o tom, jak by se měla reforma v běžných školách a tř́dách realizovat a jak by měly vypadat její výsledky, a tak trochu doufali, že odpověd získají od samotných učitelů. „Nedostatečná“ vyspělost učitelů se pak projevila v tom, že většinově nepochopili reformu jako př́ležitost zvýšit užitečnost a smysluplnost své práce a modifikovat ji tak, aby z ní získali maximální pracovní uspokojení. (2013, s. 739)

Přitom, jak je vysvětleno v poznámce, adjektivum nedostatečný není míněno pejorativně, ale věcně. Vyjadřuje názor, že aktéři nebyli připraveni na takto ambiciózní reformu.

Představuji si, jak tvůrci kurikulárních dokumentů vedou na vodítkách učitele, ač sami nemají představu, jak reformu realizovat. Vedou je tedy aspoň k implementaci reformy, kterou mají tito podle Strakové nedostatečně vyspělí dělníci pedagogiky realizovat, prioritizovat a dokomponovat... Uzavírá se „příběh jedné kurikulární reformy, kterou se nepodařilo např́íc všemi aktéry vykomunikovat a zkoordinovat" (Janík et al., 2011, s. 412).

Ladislav Kvasz poukazuje (Kvasz, 2008), že charakter matematiky se projevuje v charakteru jejího jazyka. Není dikce některých našich pedagogů obrazem úrovně části naší pedagogiky? Proč neříci jazykem srozumitelným každému učiteli, oč by nám mělo v současné škole jít. Pokusím se o to v následující části. 


\section{Jak řešit problémy matematického vzdělávání v naší škole}

Tomáš Janík vidí východisko ze současné situace $\mathrm{v}$ našich školách $\mathrm{v}$ dlouhodobém programu produktivní kultury vyučování a učení. K tomu považuje za nutné koncipovat státní kurikulum tak, aby představovalo rámec vymezující prostor pro realizaci učení, které je opřené o didaktický konstruktivismus (Janík, 2013, s. 654, 659). Otázce konstruktivismu je věnována i naše publikace. Připomenu z ní několik myšlenek. Vzdělávací proces v matematice je nutno hodnotit minimálně ze tř́ hledisek. „První je porozumění matematice, druhé je zvládnutí matematického řemesla, třetí jsou aplikace matematiky“ (Hejný \& Kuřina, 2009, s. 195).

Pro konstruktivně pojaté vyučování matematice je charakteristické aktivní vytváření části matematiky $\mathrm{v}$ duševním světě dítěte. Podle povahy žáka může být podkladem pro takovou konstrukci otázka či problém ze světa př́rody, techniky, společnosti či matematiky samé. Při řešení tohoto problému můžeme přirozeně sdělovat žáku všechny potřebné informace, vysvětlovat pojmy, odkazovat na informace v encyklopediích a příručkách, avšak vše ve službě rodící se matematiky v duševním světě žáka. Konstruktivistické vyučování tedy může obsahovat transmisi celých partií, může obsahovat i instrukce k řešení typických úloh. Matematické vzdělávání by mělo mít smysl a mělo by být užitečné. Mělo by žákům přinášet uspokojení a radost. (Hejný \& Kuřina, 2009, s. 196)

K takovémuto př́istupu k vyučování nelze dát obecný návod. Může je uskutečňovat jen „dobrý učitel“. Přitom si musíme uvědomit, že na žáky působí mnohdy negativně společnost, v níž o úspěchu člověka nerozhodují vždy jeho kvality. Univerzity mohou přispět k zlepšení práce školy především tím, že budou vychovávat dobře odborně připravené učitele, budou pomáhat $\mathrm{v}$ dalším vzdělávání učitelů a produkovat kvalitní literaturu. Připomínám, že např. Jednota českých matematiků a fyziků přispívá k zlepšení práce školy vypracováním standardů a sbírek úloh (např. Fuchs et al., 2000). „V konstruktivistickém pojímání matematiky jde o to, že učivo není chápáno jako hotový celek, ale jako něco, co se utváří" (Janík, 2013, s. 656). Škola by měla věnovat mimořádnou péči tomu, co by měli zvládnout všichni žáci bez výjimky, tedy tomu, co se někdy nazývá gramotností. 


\section{Gramotnost}

Pojem gramotnost je jedním z hojně frekventovaných pojmů současné pedagogiky. Jiřri Mareš definuje s odvoláním na americkou autorku G. Sarigovou gramotnost jako takové vědění a učení, které se snaží zpracovávat znalosti způsobem promyšleným, reflexivním a tvořivým a pokouší se využívat při tom náročnější myšlenkové operace $(2013$, s. 106). V Pedagogické encyklopedii zpracovala oddíl Gramotnost Jana Doležalová, která rozlišuje gramotnost čtenářskou, matematickou a další druhy gramotností, které tvoří základ obecné gramotnosti považované za „nezbytnou pro současného člověka - občana". Vymezení jednotlivých druhů gramotností přebírá z publikací Strakové (2002) a Úlohy pro měření čtenářské, matematické a př́rodovědné gramotnosti (2000) v tomto smyslu:

Matematická gramotnost je definována jako způsobilost rozpoznat a pochopit matematiku, zabývat se jí a být schopen podložených soudů o úloze matematiky v soukromém životě jednotlivce, v zaměstnání, ve společnosti. (Úlohy pro měření čtenářské, matematické a prrírodovědné gramotnosti, 2000, in Doležalová, 2009, s. 225).

Čtenářská gramotnost představuje [...] schopnost porozumět psanému textu, přemýšlet $\mathrm{o}$ něm a používat jej $\mathrm{k}$ dosažení vlastních cílů, $\mathrm{k}$ rozvoji vlastních vědomostí a potenciálu a $\mathrm{k}$ aktivní účasti ve společnosti. (Straková 2002, in Doležalová, 2009, s. 225)

O vztahu tzv. funkční gramotnosti a gramotnosti školní piše v citované encyklopedii Milada Rabušicová, při čemž zdůrazňuje, že „funkční gramotnost [...] představuje výlučně gramotnost dospělých“ (Rabušicová, 2009, s. 235).

Podle mého názoru nemají takto chápané pojmy pro školní praxi hlubší význam, nebot' formulace „pochopit matematiku, zabývat se jí a být schopen soudů o ní" postrádají konkrétní obsah. Proto jsem před několika léty formuloval pro potřeby didaktiky matematiky následující pojetí gramotnosti:

Matematickou gramotností na úrovni n-té třídy k-tého stupně rozumíme:

- schopnost porozumět matematickému textu (slovnímu, symbolickému nebo obrázkovému),

- schopnost vybavovat si potřebné matematické pojmy, postupy a teorie, 
- dovednost řešit úlohy jak z matematiky, tak i z jejích aplikací, které jsou (obvykle bezprostředním) užitím probraného učiva. K řešení úloh problémového charakteru je třeba určitá míra tvořivosti, která představuje vyšší úroveň matematické kultury. Základní matematickou gramotnost by ovšem měl dosáhnout každý absolvent př́slušného typu školy. Pěstování matematické gramotnosti je nejdůležitější úkol každého stupně školy (Hošpesová et al., 2011, s. 26).

Matematickou gramotnost může dobře posoudit zodpovědný učitel, jen zčásti ji lze hodnotit na základě jednorázového testování. 0 těchto otázkách jsem psal v článku (Kư̌rina, 2014).

Souhlasím s Janou Strakovou, že „učitelé, ve snaze zlepšit výsledky svých žáků $\mathrm{v}$ testech, věnují zvýšenou pozornost vědomostem a dovednostem, které jsou hodnoceny. Mnohdy tak činí na úkor jiných vědomostí a dovedností, které hodnoceny nejsou" (Straková, 2013, s. 741). Uznávám, že je třeba srovnávat úroveň vzdělání, nemyslím však, že je účelné co nejvíce rozšíríit rozsah vědomostí a dovedností ověřovaných $\mathrm{v}$ plošných testech. Vrat'me důvěru v hodnocení učitelů. Vzdělanost nelze měřit žebřričky. Bezpečný znak kvality vědce se podle současných kritérií určuje počtem bodů získaných v impaktovaných časopisech, bezpečný znak kvality žáka pak pořadím vjakýchsi testech. Obojí dává podle mého názoru obraz falešný. Řadu podnětů k zlepšení práce naší školy uvádí Tomáš Janík v citovaném článku z r. 2013.

\section{Závěr}

Považuji za nutné formulovat jasné a závazné vzdělávací cíle pro jednotlivé stupně našich škol a věnovat náležitou péči každodenní práci učitelů, včetně pomoci všude, kde se ukáže potřeba. Překotné reformy výsledky práce školy, živého organismu žáků a učitelů, mohou jen zhoršovat. To moudř́ lidé v minulosti dobře věděli. Připomenu při této př́ležitosti slova Bohumila Bydžovského, matematika, který se zabýval školskou problematikou ve třicátých letech minulého století:

Pro všechny školy a v širším pojetí pro všechny instituce v demokracii platí, aby budoucně reforma školy byla, jak bych řekl spojitá, aby se nedála za prudkých otřesů, nýbrž nenáhle a organicky. K tomu je nezbytně třeba, aby se reformního úsilí účastnili co nejvíce učitelé sami, aby konali hojně pedagogických pokusů a tak připravovali drobné kroky, jimiž by škola vytrvale kráčela ke svému zdokonalení. (Bydžovský, 1937, s. 314) 
Jsem velmi rád, že se mé didaktické přesvědčení shoduje aspoň s některými názory představitelů naší pedagogické vědy. Zejména souhlasím s názorem, že má-li mít reforma „zásadní a koncepční dopad, musí měnit 1) profesionální myšlení učitelů (jejich pojetí výuky) současně s 2) jejich reálnou činností v praxi výuky“ (Janík et al., 2011, s. 409). Školu utvářejí žáci a učitelé, kteří jsou formováni realitou společnosti, do níž přirozeně patří i jejich vzdělávání a životní zkušenosti. „Nová kultura vyučování a učení [...] vyžaduje systematickou a nově pojatou př́pravu učitelů zakotvenou ve vzdělávací praxi“ (Janík et al., 2011, s. 409). Bohužel „samotná reforma pronikavě nezměnila práci ve školství. Učitelé vyučují stejně nebo podobně jako před reformou" (Janík et al., 2010, s. 123). V podobném smyslu se vyjadřuje i jeden z našich předních učitelů matematiky Dag Hrubý ve stati z r. 2011, v níž mimo jiné upozorňuje, že dokument Bílá kniha není správně nastaven a řada cílů „V něm uvedených není naplňována nebo je nereálná“ (s. 477).

\section{Literatura}

Bydžovský, B. (1937). Naše středoškolská reforma. Praha: Profesorské nakladatelství.

Doležalová, J. (2009). Gramotnost. In J. Průcha (Ed.), Pedagogická encyklopedie (s. 223-229). Praha: Portál.

Fuchs, E., Hrubý, D., Herman, J., Chrápavá, V., \& Kubínová, M. (2000). Standardy a testové úlohy $z$ matematiky pro ZŠ a víceletá gymnázia. Praha: Prometheus.

Good, C. V. (1959). Dictionary of education. New York: McGraw-Hill.

Hejný, M., \& Kuřina, F. (2009). Dítě, škola a matematika. Praha: Portál

Hošpesová, A., Kuřina, F., Cachová, J., Macháčková, J., Roubíček, F., Tichá, M., \& Vaníček, J. (2011). Matematická gramotnost a vyučování matematice. České Budějovice: Jihočeská univerzita.

Hrubý, D. (2011). Kurikulární reforma přišla pozdě. Pedagogická orientace, 21(4), 474-480.

Janík, J. (2013). Od reformy kurikula k produktivní kultuře vyučování a učení. Pedagogická orientace, 23(5), 634-663.

Janík, T., Janko, T., Knecht, P., Kubiatko, M., Najvar, P., Pavlas, T., ... \& Vlčková, K. (2010). Kurikulární reforma na gymnáziích: výsledky dotazníkového šetření. Praha: VÚP.

Janík, T., Knecht, P., Najvar, P., Píšová, M., \& Slavík, J. (2011). Kurikulární reforma na gymnáziích: výzkumná zjištění a doporučení. Pedagogická orientace, 21(4), 375-415.

Komenský, J. A. (1946). Didaktika analytická. Praha: Samcovo knihkupectví.

Kuřina, F. (1976). Problémové vyučování v geometrii. Praha: SPN.

Kuřina, F. (2003). Oborové didaktiky a školská praxe. Pedagogika, 19(3), 321-324.

Kuřina, F. (2009). Didaktická transformace obsahu a školská praxe. Pedagogika, 25(3), 298-308.

Kuřina, F. (2014). Naše pedagogická realita. Matematika, fyzika, informatika, 23(1), 1-8.

Kvasz, L. (2008). Pattern of changes. Basel: Birkhäuser.

Mareš, J. (2001). Učení ve školním kontextu. In J. Čáp \& J. Mareš, Psychologie pro učitele (s. 384-410). Praha: Portál.

Mareš, J. (2013). Pedagogická psychologie. Praha: Portál.

Miller, H. (1995). Nexus. Olomouc: Votobia. 
Národní program rozvoje vzdělávání v České republice. Bílá kniha. (2001). Praha: VÚP.

Ouředník, P. (2013). Svobodný prostor jazyka. Praha: Torst.

Průcha, J. (2005). Moderní pedagogika. Praha: Portál.

Průcha, J. (2009). Pedagogická encyklopedie. Praha: Portál.

Rabušicová, M. (2009). Školní vzdělávání a funkční gramotnost. In J. Průcha (Ed.), Pedagogická encyklopedie (s. 235-241). Praha: Portál.

Rámcové vzdělávací programy. (2002). Praha. VÚP.

Selye, H. (1975). K záhadám vědy. Praha: Orbis.

Straková, J. (2013). Jak dál s kurikulární reformou. Pedagogická orientace, 23(5), 734-743.

Straková, J., Kašpárková, L., Kramplová, I., Palečková, J., Procházková, I., Raabová, E., \& Tomášek, V. (2002). Vědomosti a dovednosti pro život. Praha: ÚIV.

Struik, D. J. (1963). Dějiny matematiky. Praha: Orbis.

Štech, S. (2013). Když je kurikulární reforma evidence-less. Pedagogická orientace, 23(5), 615-633.

Úlohy pro měření čtenářské, matematické a př́rodovědné gramotnosti (2000). Praha: ÚIV.

\section{Autor}

Prof. RNDr. František Kuřina, CSc., Univerzita Hradec Králové, Př́rodovědecká fakulta, Katedra matematiky, Rokitanského 62, 50003 Hradec Králové, e-mail: frantisek.kurina@uhk.cz

Zápotočná, O. (2013). Metakognitívne procesy v čítaní, učení a vzdelávaní. Trnava: Typi Universitatis Tyrnaviensis (VEDA).

Publikácia otvára staro-novú tému kognitívnej regulácie poznávania, ktorá sa v súčasnosti - najmä v súvislosti s výsledkami medzinárodných výskumov čitatel'skej gramotnosti (PISA) stala pomerne populárnou, aj ked’ tak trochu stále záhadnou, plnou nejasností, ale aj snáh o často zjednodušujúce riešenia problémov spojených s učením a vzdelávaním. Autorka monografie prezentuje tému metakognície v širšom kontexte jej historického vývinu v psychologickom skúmaní, ako aj z hladiska jej genézy v kognitívnom vývine diet’at’a. Prináša údaje nakumulované v posledných dekádach, poukazujúce na to, že vývinové korene metakognície, t.j. vedomej regulácie poznávania siahajú pomerne hlboko do predškolského veku v závislosti od podmienok sociálneho prostredia. Ťažiskom publikácie je skúmanie metakognitívnych procesov a stratégií, ktoré významným spôsobom vstupujú do procesu čítania, a to už od jeho počiatkov, v čase osvojovania si základov písanej reči. Edukačné odkazy publikácie sú preto smerované predovšetkým do oblasti primárneho vzdelávania. 